\title{
MULTI-CRITERIA ANALYSIS (MCA) FOR FISHERIES MANAGEMENT IN MARINE CONSERVATION AREA, KAPOPOSANG ISLANDS
}

\section{(Multi-Criteria Analysis (MCA) Untuk Pengelolaan Perikanan Di Kawasan Konservasi Laut, Pulau Kapoposang)}

\author{
Yonvitner'), Lukman Faisol'), Yasir'²), Ilham²) \\ ${ }^{1)}$ Department of Aquatic Resources Management, Faculty of Fisheries and Marine Science IPB \\ University dan Centre for Disaster Studies (CERDAS) IPB. \\ ${ }^{2)}$ Official staff of BPSPL Maros Representative, Management Area in Kapoposang Conservation
} Area.

\begin{abstract}
Multi-criteria analysis has been used widely in the conservation project, especially in the assessment of coastal zones and small islands. In its application to the conservation area, Kapoposang was developing a multi-criteria approach to determine the no-take zone, utilization zone, and sustainable fisheries zone. The multi-criteria approach in Kapoposang constructed by biophysics, ecology, economy and social aspect. Decisions were taken after aggregate analysis of all criteria (Brawn et al 2001) done. The results obtained that the suitable island for the no-take zone is Kapoposang and Suranti Island. Tambakulu Island and Pemangangan were selected as a buffer zone. Finally, the sustainable fisheries zones are Papandangan and Gondongbali island. The spatial analysis of all regional boundaries determined by the three zones reached a total area of 50011.35 ha. Thus the conservation management plan design in each zone were characteristic by different function and management system.
\end{abstract}

Keyword: Zonation, Multi Criteria, Conservation Are, Kapoposang Island, Management plan

\begin{abstract}
ABSTRAK
Analisis multi kriteria secara umum sudah sangat luas penggunaanya dalam penelitian konservasi, khusuny untuk penilaian di wilayah pesisir dan pulau-pulau kecil. Dalam hal ini, untuk wilayah konservasi perairan laut Kapoposang, penelitian ini mengujikan pendekatan multi kriteria untuk menentukan kawasan inti, kawasan pemanfaatan dan zona perikanan perikanan berkelanjutan. Pendekatan multi kriteria di kapoposang disusun dari aspek biofisik, ekologi, ekonomi dan social. Keputusan akan diambil setelah analisis agregat dari semua kriteria menurut (Brawn et al 2001) didapatkan. Hasil yang diperoleh menunjukan bahwa pulau cocok untuk kawasan zona inti adalah pulau Kapoposang dan Suranti. PulauTambakulu dan Pemanggangan terpilih sebagai kawasan penyangga. Kemudian zona perikanan berkelanjutan adalah pulau Papandangan dan Gondongbali. Analisis spasial dari semua semua wilayah dikaji tercatat total luas wilayah mencapai 50011.35 ha. Sehingga kemudin rencana aksi konservasi dirancang ditiap zon sesuai dengan perbedaan karakternya serta fungsi.

Kata kunci : Zonasi, Multi Kriteria, Konservasi, Kepulauan Kapoposang, Rencana Pengelolaan
\end{abstract}




\section{INTRODUCTION}

One of the National Marine Conservation Area (MNCA) is the aquatic tourism park (atp/twp) in Kapoposang in South Sulawesi, has an area about $\pm 50,000$ ha. The marine conservation area in kapoposang not only are being recognized to promote biology and diversity, but also for social system (SES) resilience. Therefore MNCA zone shall consist of biophysics, biology, social economy, and legislation dimension. The MCA built as dedicated to conservation biodiversity that has the character to enable to be considered as an institution (Villalabos 2000 in Azcona 2019) to the successful management plan.

The aquatic tourist park (twp) Kapoposang was located in Makassar Strait which consists of several small islands. Around the coastal and small island was found coral, mangrove and fisheries ecosystem. All communities in these islands have an economic value that good advantages to local people. Fisheries practices carried out and often uncontrolled and then cause many damages to ecosystem sustainability and fisherman welfare. The result is the destruction of coral ecosystems, mangroves, seagrasses and the overexploitation of fish resources. Increasing the population also requires an increase in the supply of resources in the long term, so that they can support life in a sustainable manner. For this reason, resource utilization in the Kapoposang area must be arranged in a certain space with zoning. In practice, all of program and management plan

This conservation management plan will become a framework of policies, procedures, and responsibilities in the framework of organizing, decision making among various government institutions regarding agreements on the use of resources or development activities in the designated zones. The current need for management practice criteria MPA to adopt more participatory and local wisdom and another local approach (Ferro-Azcona et al, 2019).

In order for the function of the conservation area to play an optimal role, it is necessary to design a management scheme according to the zone. The zone to be studied consists of the no-take zone as a protection space from utilization activities except for research, the buffer zone as a limited utilization space, as well as the production zone as a common fisheries zone. For this reason, it is necessary to do a good scientific justification by considering the biophysical, ecological, economic, socio-cultural aspects of technology and the environment so that the existing zone is able to represent the conditions of all aspects.

Coastal and Small Island are setting busier and increasingly human activity, push marine biodiversity to decline and as the impact of economic activity. Often conservation programs and production become a trade-off in the same location (Yates, 2015). For this reason, many researchers are now popularizing the technique of analyzing many parameters (multi-criteria) in analyzing each of these spaces. The results of the analysis are then plotted in a spatial distribution map to determine the area and zone boundaries that are set. This study aims to determine the notake zone, buffer zone, and sustainable fisheries zone of a conservation area with a multi-criteria approach from biophysical, ecological, social and economic indicators.

\section{MATERIAL AND METHOD}

The study was conducted in a group of small islands in the Kapoposang of Makassar Strait. Administratively it is in the management area of Pangkajene Kepulauan Regency, where the geographically study location (figure 1). 


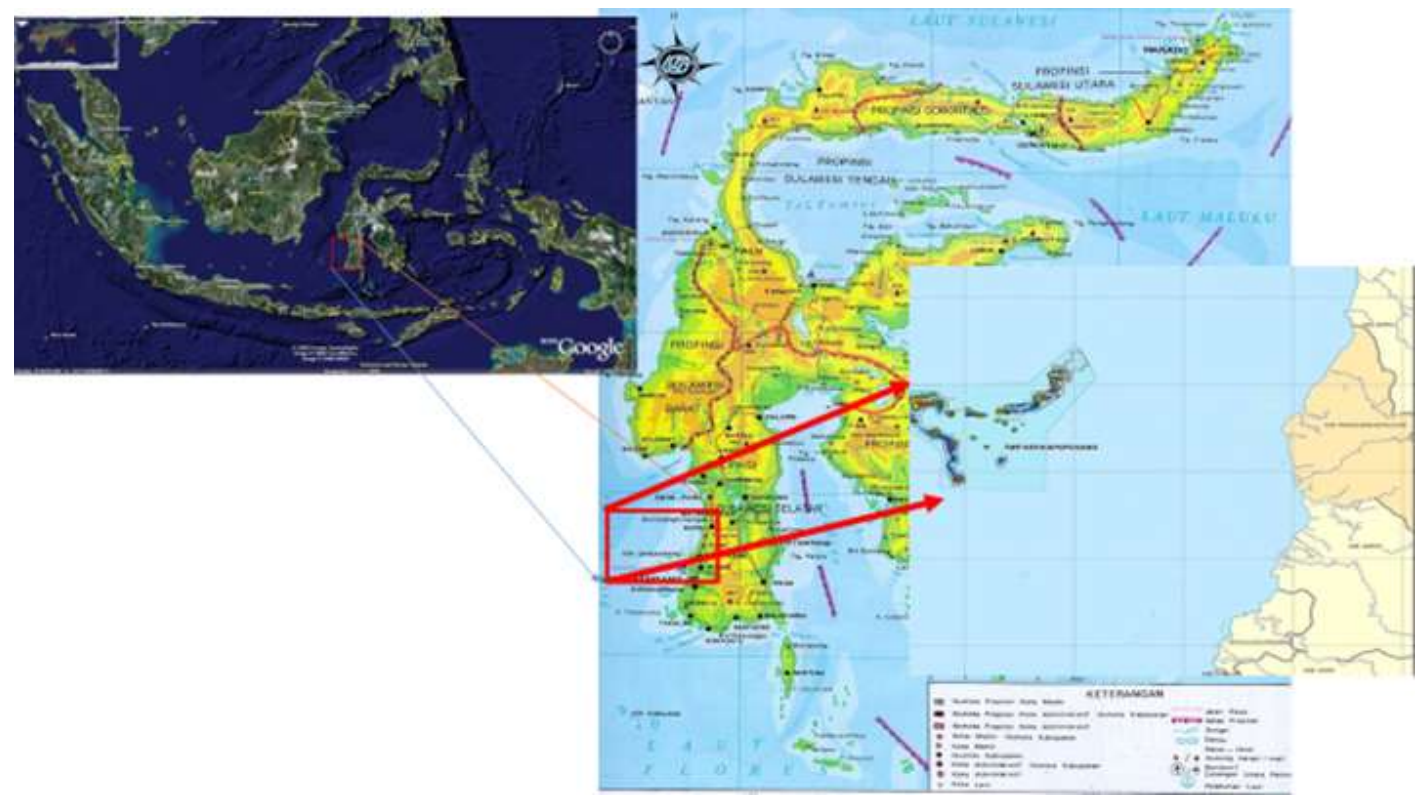

Fig 1. Research location in Kapoposang Conservation Area

Priority locations to be assessed are 6 islands are Kapoposang, Gondongbali, Papandangan, Pamangangan, Tambakulu and Suranti islands. The delineation of zones (no-take, buffer, or utilization) will be analyzed using a multi-criteria analysis (MCA) approach. MCA is a general approach that can be used to analyze complex problems involving multiple criteria (Adrianto et al, 2005). The $4^{\text {th }}$ criteria analyze are biophysical, ecological, economic and social with their respective parameters studied in a composite manner. Biophysical criteria consist of flow, brightness, and wave exposure also particle structure parameter, as well as the extent of coral stretches. Ecological criteria consist of seagrass diversity, seagrass density, seagrass coverage, coral diversity, coral density, biota associate. The economic criteria consist of the value of coral fish diversity, coral fish density, and fishes productivity. And then the social criteria are the level of connectivity between location, accessibility, and local socialcultural values, population. The four criteria are chosen, although there are very many other criteria that can be used as a basis for assessment such as the diversity index, and fisheries index (Mourao, et al 2014).

These fourth criteria were chosen as parameters that will be referred to as zone determination using the multicriteria analysis (MCA) technique. The values from each criterion will be scaled to determine zonation from each location. The analysis method is carried out as follows (Brown et al 2001) below.

$$
X_{s}=\frac{X-X \min }{X \max -X \min } \times 100
$$

Where:

$\mathrm{Xs}=$ Value that is calculate in each parameter; $\mathrm{X}=$ existing value;

$\mathrm{X}_{\max }=$ Maximum Value in one parameter;

$\mathrm{X}_{\min }=$ Minimum value one parameter was calculated.

This conversion formula applies if the value is greater means the better the reference limit. For value macroeconomic criteria values $(9,11$, 17 , and 19) the score is obtained 0,20 , 80 and 100 . The score given is between 0-100. If instead the smaller the parameter value that explains the better the parameter, then the model as follows (Brown et al 2001). 


$$
X_{s}=\frac{X \max -X}{X \max -X \min } \times 100
$$

This conversion formula applies if the value is smaller means the better the reference. Where: $X s=$ Value that is score; $X=$ the value that will be changed into the score; $X_{\max }=$ Maximum Value that found $(=2.2) X_{\text {min }}$ $=$ Minimum value $(=1.4)$. For example, for the water quality criteria, has values $(1.4,1.5,1.9$ and 2.2) the scores are obtained 100, 88, 38, and 0 . The multicriteria model also referred to as the integrated model of the complex model of each indicator observed (Ascough II, et al, 2008). Furthermore, a composite analysis was performed to determine the total value of the observed parameters. At the end of the subsequent process is the display of data analysis in the spatial model for prioritizing zone for conservation area (Manea, 2019).

At the end of this research is delineate 3 zonations were, the first notake zone (restricted access zone), buffer zone and sustainable fisheries zone. Restricted access zone (no entry and no-take zone): the zone is designed to protect and conserve biodiversity both in pristine or recovery conditions without human fishing. The exception that approved for scientific research and monitoring (Hatemarian and Fang, 2016). Buffer zone provides to conserve biodiversity as a nursery ground, where has limited access to commercial fishing. The main activity for humans as a tourism area or recreational fishing user-friendly like handline. And the sustainable fisheries zone is a zone for commercial fishing in limited access refer to quota or total allowable catch. The fishing process in this area is a focus on manageable fisheries (Habtemarian and Fang, 2016). Totally MPA will contribute to conserving the nursing and breeding habitat of coral fishes and another marine biota (Sarker et al, 2019) in Kapoposang archipelagic.

\section{RESULT AND DISCUSSION}

Result

Kapoposang islands have rocky and rubble substrate with high wave exposure from wave and tidal in Makassar Strait. Around the coastal and small island area was dominated by coral reefs with coral fish and seagrasses. In general, this ecosystem provides services for fisheries that are utilized by communities in the region. The level of resource utilization is relatively high, especially on inhabited islands. The recording data from the study in each criteria are as follows (Table 1).

The six locations were chosen relatively categories as a large island in the Kapoposang conservation area. The whole of the population has good connectivity to natural resources. The values of all ecological, economic and social criteria (Table 2) ware transformed into categories data. The results of the category data analysis from the scoring approach of each parameter with the according to category formula (Brown, et al, 2001) are presented in the following Table 2. Based on biophysical criteria, the Kapoposang and Suranti Islands record as the highest value compared to other islands. The highest score for ecological criteria also both Kapoposang and Suranti Island. And then economic criteria, the highest average score are Kapoposang and Tambakulu Island, as well as social criteria on Tambakulu Island and Suranti Island. Cumulatively aggregate of all criteria, scores obtained on Kapoposang Island was 74.7, score on Suranti Island 56, Tambakulu Island 46.9, Pagdanganan Island 35.9, Gondongbali Island 29.8 and Papandangan Island score its about 25.9. Thus, in general, the results 
obtained from the assessment are that the Kapoposang and Suranti island is better considered as the no-take zone in the Kapoposang marine conservation area. Contributions from each criterion on the island region are observed as follows (figure 2). Although composite criteria, some time to evaluated ecosystem status, ecology criteria only can be used to delineating and mapping selected zone (Assad et al, 2018).

Table 1. Value of each parameter in each islands record

\begin{tabular}{|c|c|c|c|c|c|c|c|c|}
\hline \multirow{2}{*}{ No } & & \multicolumn{7}{|c|}{ Island No } \\
\hline & & Unit & 1 & 2 & 3 & 4 & 5 & 6 \\
\hline A & Biophysical & & & & & & & \\
\hline 1 & Transparency & $\mathrm{m}$ & 10.6 & 6.14 & 7 & 7.25 & 6.25 & 6.25 \\
\hline 2 & Substrate & - & Rubble & $\begin{array}{l}\text { dead } \\
\text { coral }\end{array}$ & rubble & $\begin{array}{l}\text { dead } \\
\text { coral }\end{array}$ & Rubble & Rubble \\
\hline 3 & Wave exposure & - & $\begin{array}{l}\text { Full } \\
\text { exposure }\end{array}$ & $\begin{array}{l}\text { Full } \\
\text { exposure }\end{array}$ & $\begin{array}{l}\text { Full } \\
\text { exposure }\end{array}$ & $\begin{array}{l}\text { Full } \\
\text { exposure }\end{array}$ & $\begin{array}{l}\text { Full } \\
\text { exposure }\end{array}$ & $\begin{array}{l}\text { Full } \\
\text { exposure }\end{array}$ \\
\hline B & Ecology & & & & & & & \\
\hline $1 a$ & Coverage $3 \mathrm{~m}$ & $\%$ & 25 & 38 & 27 & 23 & 16 & 10 \\
\hline $1 b$ & Coverage $10 \mathrm{~m}$ & $\%$ & 28 & 28 & 13 & 26 & 32 & 12 \\
\hline 2 & Coral Genera & Gen & 16 & 15 & 12 & 13 & 14 & 10 \\
\hline 3 & Coral Status & $\%$ & 44 & 35 & 80 & 97 & 47 & 34 \\
\hline 4 & Seagrass Diversity & Sp & 8 & 2 & 1 & 3 & 5 & 0 \\
\hline 5 & Seagrass Density & $\operatorname{lnd} / \mathrm{m}^{2}$ & 316 & 106 & 350 & 417 & 0 & 0 \\
\hline 6 & Biota associate & $\mathrm{Sp}$ & 6 & 6 & 2 & 2 & 6 & 2 \\
\hline C & Economy & & & & & & & \\
\hline 1 & Fish's Density in $3 \mathrm{~m}$ & $\mathrm{Ind} / \mathrm{m}$ & 512 & 457 & 366 & 293 & 342 & 526 \\
\hline 2 & Fish's Density in $10 \mathrm{~m}$ & $\operatorname{lnd} / \mathrm{m}^{2}$ & 506 & 362 & 195 & 352 & 374 & 308 \\
\hline 3 & Coral fish genera $3 \mathrm{~m}$ & Gen & 27 & 23 & 20 & 23 & 25 & 25 \\
\hline 4 & Coral Fish species 3 m & Ind & 39 & 33 & 30 & 32 & 37 & 34 \\
\hline 5 & $\begin{array}{l}\text { Coral Fish Genera } 10 \\
\mathrm{~m}\end{array}$ & Ind & 29 & 27 & 25 & 25 & 26 & 17 \\
\hline 6 & Corl Fish Species $10 \mathrm{~m}$ & Ind & 41 & 37 & 35 & 34 & 39 & 21 \\
\hline 7 & Fish Biomass in $3 \mathrm{~m}$ & $\mathrm{Kg} / \mathrm{ha}$ & 6820 & 6087 & 4875 & 3903 & 4555 & 7006 \\
\hline 8 & Fish Biomass in $10 \mathrm{~m}$ & (kg/ha) & 6740 & 4822 & 2597 & 4689 & 4982 & 4103 \\
\hline 9 & $\begin{array}{l}\text { Average of Economy } \\
\text { value } 3 \mathrm{~m}\end{array}$ & $\begin{array}{r}(\text { IDR/ha } \\
\left.\times 10^{6}\right)\end{array}$ & 238,6944 & 213,0534 & 170,6292 & 136,5966 & 159,4404 & 245.2212 \\
\hline 10 & $\begin{array}{l}\text { Average of Economy } \\
\text { value } 10 \mathrm{~m}\end{array}$ & $\begin{array}{r}(\text { IDR/ha } \\
\left.\times 10^{6}\right)\end{array}$ & 235,8972 & 168,7644 & 90,909 & 164,1024 & 174,3588 & 143,5896 \\
\hline D & Social & & & & & & & \\
\hline 1 & Utilization area & - & Fully & Fully & Medium & Medium & Fully & Fully \\
\hline 2 & Accessibility & Grade & 6 & 4 & 4 & 5 & 4 & 5 \\
\hline 3 & $\begin{array}{l}\text { Perception of the local } \\
\text { community as } \\
\text { conservation are }\end{array}$ & - & agree & agree & agree & agree & agree & agree \\
\hline 4 & $\begin{array}{l}\text { The intensity of local } \\
\text { mobility }\end{array}$ & Freq & Medium & medium & high & high & high & Low \\
\hline 5 & Population & Person & 484 & 1171 & & & & 853 \\
\hline
\end{tabular}


Table 2. New data transform of each parameter from Table 1.

\begin{tabular}{|c|c|c|c|c|c|c|c|}
\hline \multirow{2}{*}{ No } & \multirow{2}{*}{ Parameter } & \multicolumn{6}{|c|}{ Islands } \\
\hline & & 1 & 2 & 3 & 4 & 5 & 6 \\
\hline $\mathbf{A}$ & Biophysical & & & & & & \\
\hline 1 & Transparency (max m) & 100 & 40 & 80 & 60 & 0 & 60 \\
\hline 2 & Substrate & 100 & 50 & 100 & 100 & 100 & 100 \\
\hline \multirow[t]{2}{*}{3} & Wave exposure & 50 & 0 & 50 & 0 & 0 & 0 \\
\hline & Average & 83 & 30 & 77 & 53 & 33 & 53 \\
\hline B & Ecology & & & & & & \\
\hline 1 & Coral reef & 100.0 & 0.0 & 23.7 & 14.2 & 29.6 & 48.5 \\
\hline 2 & Coral Diversity & 100.0 & 66.7 & 33.3 & 0.0 & 100.0 & 33.3 \\
\hline 3 & Coral Status & 15.9 & 1.6 & 73.0 & 100.0 & 20.6 & 0.0 \\
\hline 4 & Seagrass Diversity & 100.0 & 25.0 & 12.5 & 37.5 & 62.5 & 0.0 \\
\hline 5 & Seagrass Density & 75.8 & 25.4 & 83.9 & 100.0 & 0.0 & 0.0 \\
\hline 6 & Other Biotic & 100.0 & 80.0 & 40.0 & 20.0 & 0.0 & 0.0 \\
\hline \multirow[t]{2}{*}{ C } & Average & 81.9 & 33.1 & 44.4 & 45.3 & 35.4 & 13.6 \\
\hline & Economy & & & & & & \\
\hline 1 & Coral Fish Diversity & 0.0 & 0,0 & 0.0 & 0.0 & 0.0 & 0.0 \\
\hline 2 & Fish Abundance & 100.0 & 25.7 & 0.0 & 0.0 & 0.0 & 0.0 \\
\hline \multirow[t]{2}{*}{3} & Biomass & 50.0 & 0.0 & 100.0 & 50.0 & 50.0 & 0.0 \\
\hline & Average & 50.0 & 12.9 & 50.0 & 25.0 & 25.0 & 0.0 \\
\hline D & Social & & & & & & \\
\hline 1 & Utilization area & 0 & 0 & 100 & 100 & 0 & 0 \\
\hline 2 & Accessibility & 0 & 100 & 100 & 50 & 100 & 50 \\
\hline 3 & $\begin{array}{l}\text { Participation of local } \\
\text { community }\end{array}$ & 100 & 0 & 100 & 100 & 100 & 100 \\
\hline 4 & $\begin{array}{l}\text { Intensity of local } \\
\text { community }\end{array}$ & 50 & 50 & 0 & 0 & 0 & 100 \\
\hline \multirow[t]{2}{*}{5} & Population & 100 & 0 & & & & 46 \\
\hline & Average & 50 & 30 & 75 & 62.5 & 50 & 59 \\
\hline
\end{tabular}

Note: 1) Kapoposang, 2) Gondongbali, 3) Tambakulu, 4) Suranti, 5) Pamangangan, 6) papandangan

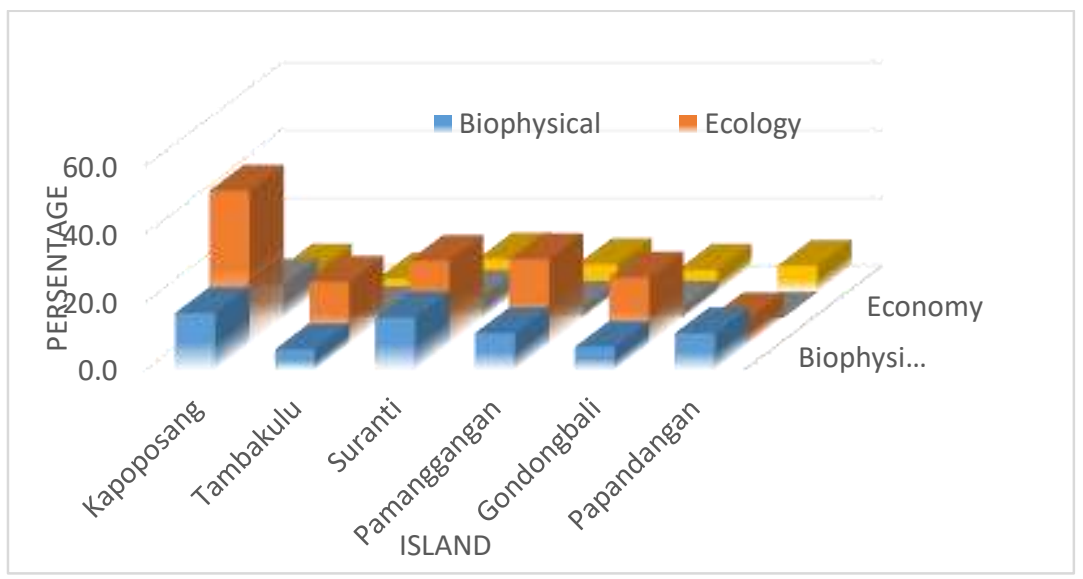

Fig 2. The proportion of biophysical, ecology, economy and social aspect 
The biophysical values of the six islands relatively have similarities, ranging from 6.7 to 16.7 of the total parameters assessed. Ecological criteria were seen the highest in Kapoposang and Tambakulu compared to another area. While the economic criteria are relatively low on all islands, as well as social criteria. Overall the aggregated values show that in this assessment, the contribution of ecological criteria is very dominant if compare from the other parameters. The composite values of all these criteria are then used as a basis for zoning.

\section{Zoning}

The fisheries zonation divide into three main areas no-take zones, buffer zones, and sustainable fisheries zones. The no-take zone area is designated area that has scored above of 50points and selected of Kapoposang and Suranti Island. The buffer zone is designated area with aggregate score values between 30-50 point is Tambakulu and Pemanggangan Island. As well as sustainable fisheries zones, designated Gondongbali and Papandangan Islands. And as a result of the evaluation of all parameters, the aggregate values of all the criteria evaluated areas figure 3 .

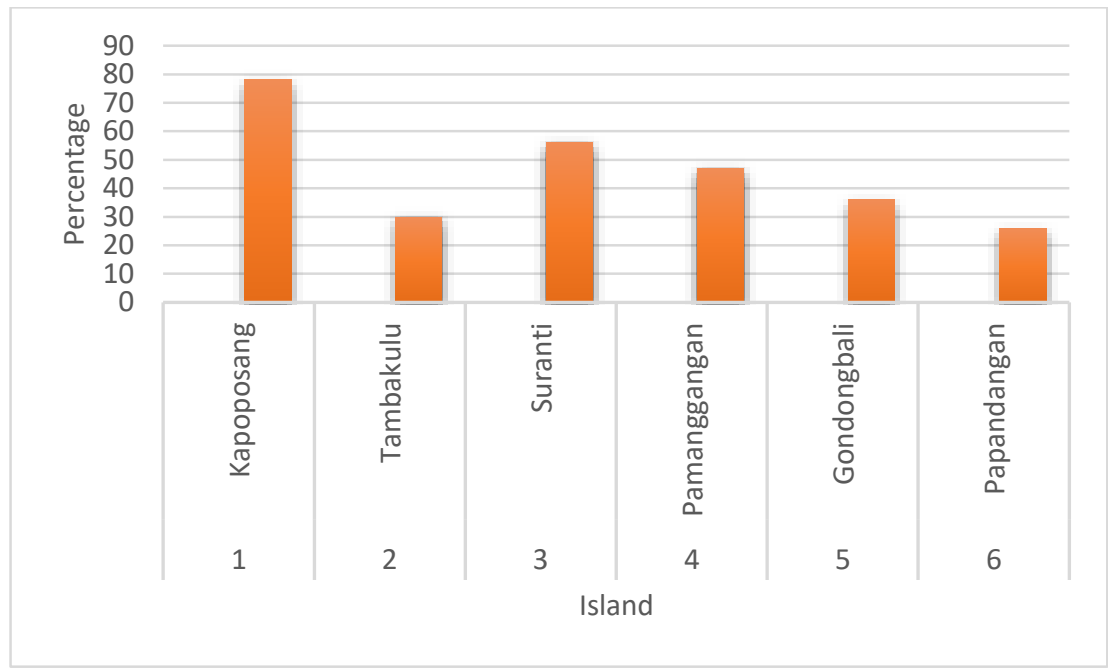

Fig 3. The aggregate value of multi-criteria at each island

Determination of no-take zones in the interconnected fisheries space is needed to maintain the balance of risks from commercial fishing that will be caused by economic performance change that obtained (Gourguet, 2014) by fisherman. No take zone is protecting valuable or sensitive habitat and management within three sites may have resulted in less fishing pressure (Nelson and Burnside, 2019).

\section{Discussion}

The spatial model was used to highlight the area of the marine environment which could be prioritized for conservation area (Manea, 2019) and intervention management (Nelson and Burnside, 2019). Spatial analysis in these study areas, the no-take zone in Suranti and Kapoposang islands, the covered area about 1082 ha (2.164\%) of the total area assessed or equivalent to $20.09 \mathrm{~km}^{2}$ with coordinates code are from no 16-19 and no 10-15 that describe in spatial map. The extent of the analyzed buffer zones reached or limited to an area of $9,589.49$ ha $(19.17 \%)$ of the total area assessed. While the sustainable fisheries area 
reached an area of 39,339.54 (78.6\%) of the total area assessed.

The spatial distribution pattern of the study area in the no-take zone, buffer zone and utilization is in one area of planning. Each zone is limited by certain coordinates that are imaginary, and thematic boundaries. Zoning was needed to conserve biodiversity, mitigating conflict, stock enrichment and accommodating multiple uses (Yates, et al 2015) and avoid recruitment overfishing (Roselto et al 2015). The suitability map in each zone describes in color red zone, green, and blue are shown in fig 4. Red zone (no- take zone) are found mainly within in two islands. More suitable area for the green zone that calls as buffer zone more widely than red zone. And the last is the blue zone called as sustainable fisheries, mainly for fishing activity. Each area has different sensitivity, particularly in red one as protective are most sensitive (Genelti and Duren, 2018). A protected area zone is an approach that can reduce conflict by partitioning the landscape into various land used that are managed for a different level of criteria and development (Nelson and Burnside, 2019).

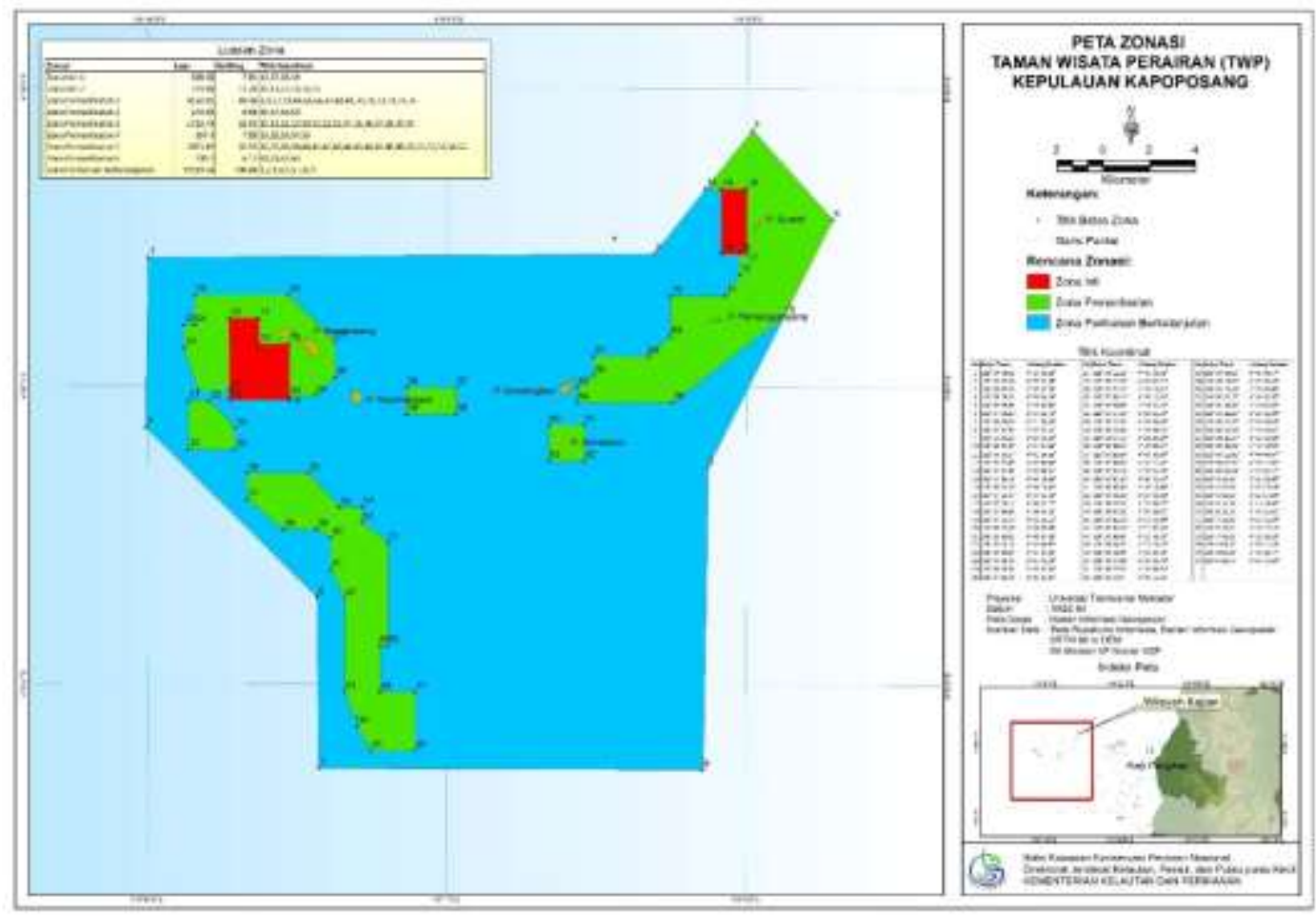

Fig 4. Zonation of the Kapoposang conservation area (source map: KKP, 2013)

The conservation area of Kapoposang which was delineated and designated as the no-take zone is the area to be reserved for the conservation of fish resources and another biota. So it needs to be prepared for various strategic steps for better regional governance in the future. The results of the analysis of the utilization of the activity plan in each space of each zone are determined as follows. One important note is that there is a rehabilitation zone, especially in areas that are damaged in each zone.

The results of the focus group discussion and participatory decision analysis are formulated as many as 26 types of activities that can be done (Esteves and Gelcich 2015) in MPA. The participative planning in MPA has 
mostly focused to identify fundamental objectives and trade-off to the maintenance of a sustainable economy in the local area (Estevez, 2015). But not all activities can be carried out in the existing zone. Because culturally the area is a traditional fishery area, it is important to establish a long-term plan to ensure the sustainability of its spatial use.

\section{CONCLUSION}

The results of the assessment of fisheries zonation in conservation area Kapoposang Islands, the no-take zone was designated on the Kapoposang and Tambakulu Island with an area $(2.16 \%)$, a buffer zone of $19.17 \%$ and the rest as sustainable fisheries. Although overall the no-take zone and buffer zones are fewer, it is expected to be a source of fish biomass production to meet the needs of the Kapoposang community in economic perspective. The aggregate scoring system of multicriteria is very important to ensure that the policies taken take many things into account and are comprehensively evaluated.

\section{ACKNOWLEDGMENT}

Thank you to the BPSPL Maros for helping the author in collecting and analyzing the data needed for this zoning analysis, namely Lukman Faisol, Yasir and IIham and Centre for Coastal and Marine Resources Studies, IPB University.

\section{REFERENCE}

Adrianto L, Y Matsuda, Y Sakuma. 2005. Assessing local sustainability of fisheries system: a multi-criteria participatory approach with the case of Yoron Island, Kagoshima Prefecture, Japan. Marine Policy 29 (2005) 9-23.

DOI:10.1016/j.marpol.2004.01.0 04

Asaad I, C J. Lundquist, MV. Erdmann, MJ. Costello. 2018. Delineating priority areas for marine biodiversity conservation in the Coral Triangle. Biological Conservation 222 (2018) 198211.

https://doi.org/10.1016/j.biocon.2 018.03.037

Ascough II JC, H.R.Maier, J.K.Ravalico, M.W. Strudley. 2008. Future research challenges for the incorporation of uncertainty in environmental and ecological decision-making. ecological modeling 219 (2008) 383-399.

DOI:10.1016/j.ecolmodel.2008.0 7.015 .

Brown K, Tompkins E, and Adger WN. 2001. Trade-Off Analysis for Participatory Coastal Zone Decision Making. ODG DEA. Csserge EUA Norwich

Estévez RA, S Gelcich. 2015. Participative multi-criteria decision analysis in marine management and conservation: Research progress and the challenge of integrating

value judgments and uncertainty. Marine Policy 61 (2015) 1-7. http://dx.doi.org/10.1016/j.marpo I.2015.06.022

Ferro-Azcona. H, A Espinoza-Tenorio, $\mathrm{R}$ Calderón-Contreras, VC. Ramenzoni, MMG País,

M Azahara Mesa-Jurado. 2019. Adaptive capacity and socialecological resilience of coastal areas: A systematic review. Ocean and Coastal Management 173 (2019) 36-51. Ocean and Coastal Management 173 (2019) $36-51$

Geneletti G, Iris van Duren. 2008. Protected area zoning for conservation and use: $A$ combination of spatial multicriteria and multiobjective evaluation. Landscape and Urban Planning 85 (2008) 97110. 
doi:10.1016/j.landurbplan.2007.1 0.004

Habtemariam BT, Q Fang. 2015. Zoning for a multiple-use marine protected area using spatial multi-criteria analysis: The case of the Sheik Seid Marine National Park in Eritrea. Marine Policy 63 (2016) 135-143. http://dx.doi.org/10.1016/j.marpo I.2015.10.011

Manea E, DD Carlo, D Depellegrinb, T.Agardyc, E.Gissi. 2019. Multidimensional assessment of supporting ecosystem services for marine spatial planning of the Adriatic Sea. Ecological Indicators 101 (2019) 821-837. https://doi.org/10.1016/j.ecolind. 2018.12.017

Mourao KRM, PWM Sousa Filho, PJ de Oliveira Alves, FL Fredou. 2014. Priority areas for the conservation of the fish fauna of the Amazon Estuary in Brazil: A multicriteria approach. Ocean \& Coastal Management 100 (2014) $116 \mathrm{e} 127$.

http://dx.doi.org/10.1016/j.oceco aman.2014.08.007

Nelson K, NG. Burnside. 2019. Identification of marine management priority areas using a GIS-based multicriteria approach. Ocean and Coastal Management 172 (2019) 82-92. https://doi.org/10.1016/j.ocecoa man.2019.02.002
Rossetto M, I Bitetto, MT Spedicato, G Lembo, M Gambino, P Acadia, P Melià. 2015. Multi-criteria decision-making for fisheries management: A case study of Mediterranean demersal fisheries. Marine Policy 53 (2015) 83-93. http://dx.doi.org/10.1016/j.marpo I.2014.11.006

Sarker S, MM Rahman, AK Yadav, MM Islam. 2019. Zoning of marine protected areas for biodiversity conservation in Bangladesh through socio-spatial data. Ocean and Coastal Management $173 \quad$ (2019) 114-122. https://doi.org/10.1016/j.ocecoa man.2019.03.002

Yates KL, DS. Schoeman, CJ. Klein. 2015. Ocean zoning for conservation, fisheries and marine renewable energy: Assessing trade-offs and colocation opportunities. Journal of Environmental Management 152 (2015) $201 \mathrm{e} 209$. http://dx.doi.org/10.1016/j.jenvm an.2015.01.045

Gourguet S, O.Thébaud, Dichmont C, S.Jennings, L.R.Little, S.Pascoe, R.A.Deng, L.Doyen. 2014. Risk versus economic performance in a mixed fishery. Ecological Economics 99 (2014) 110-120. http://dx.doi.org/10.1016/j.ecolec on.2014.01.013 